\title{
Ultrastructural Features of Ovary of the Female African Giant Rat (Cricetomys gambianus, Waterhouse) During Oestrous Cycle
}

\author{
Características Ultraestructurales Durante el Ciclo Estral del Ovario \\ de Rata Gigante Africana (Cricetomys Gambianus, Waterhouse)
}

\author{
Adebayo Koyuum Akinloye* \& Bankole Olusiji Oke**
}

\begin{abstract}
AKINLOYE, A. K. \& OKE, B. O. Ultrastructural features of ovary of the female African giant rat (Cricetomys gambianus, waterhouse) during oestrous cycle. Int. J. Morphol., 32(2):558-567, 2014.

SUMMARY: Fine structures of the ovary during the oestrous cycle in African giant rats (Cricetomys gambianus Waterhouse) were described in the present study. Ultrastructural features of the germinal epithelium and the medullar of the ovary were similar at different stages of the oestrous cycle. During mid proestrus, there was disorganization of the inner layer of the granulosa cells of secondary follicles to form the antrum. At late proestrus/early estrus, antrum formation had advanced and there was evidence of reorganization of granulosa cells. Fine structures of the ovary during mid estrus include follicles with variably shaped mitochondria, profiles of Golgi complexes and dense concentration of ribosomes. The theca interna shared similar ultrastructure with the granulosa cells containing, in addition, lipid droplets and smooth endoplasmic reticulum. Cellular ultrastructure observed during mid metestrus showed commencement of differentiation of corpus luteum. At mid diestrus, the general ultrastructural architecture of the ovarian follicles showed disorganized cellular contents and corpus luteum was recognized with conspicuous depolarization of the basement membrane originally separating granulosa cells from the theca. At late diestrus/early proestrus, granulosa cells displayed numerous mitochondria of variable sizes and shapes. Ribosomes were evenly distributed throughout the cytoplasm while electron lucid vesicles were sparsely distributed. The results of this study showed that fine structural changes in the ovary of the giant rat during the oestrous cycle are similar to those of laboratory rodents.
\end{abstract}

KEY WORDS: Ultrastructure; Ovary; Oestrous Cycle; African Giant Rat.

\section{INTRODUCCIÓN}

The African giant rats (Cricetomys gambianus, Waterhouse) have a wide distribution, occurring everywhere in Africa. Thus, the species is adapted to a wide variation in climate and ecological zones. This kind of adaptations to various environmental conditions is an attribute that was observed to be an important criterion in selecting animals for domestication (Ajayi, 1977). They are in great demand as protein supplements as rodents form a significant portion of the total amount of bush-meat consumed in West Africa today. They are prolific rodents as Ajayi (1974) observed one female to give birth five times in 9 months and concluded that probably female could produce 10 litters annually. The gestation perios was 27-36 days, usually 30 - 32, days. Litters numbered $1-5$, most commonly 4 , young. Thus, the economic potential of the giant rats necessitates the in-depth research being conducted into their reproductive biology.
The ovaries are paired organs suspended from the broad ligament of the uterus in a fold of peritoneum called the mesovarium. They are both endocrine (estrogen, progesterone, and androgen-secreting) and exocrine (ovum-producing) glands (Eurell \& Frappier, 2006). The shape, size and weight of the ovaries vary with both the species and the stage of the oestrous cycle (Hafez, 1970; Fawcett \& Jensh, 2002). Akinloye \& Oke (2009) characterized the gross morphometry of ovaries of the female African giant while Madekurozwa et al. (2010) evaluated some aspects of the immunohistochemistry and histology of the ovary in this species. Therefore, the present study was undertaken to investigate the ultrastructure of the ovary during oestrous cycle in order to complement the previous studies.

\footnotetext{
* Department of Veterinary Anatomy, Federal University of Agriculture, Abeokuta, Nigeria.

** Department of Veterinary Anatomy, University of Ibadan, Ibadan, Nigeria.
} 


\section{MATERIAL AND METHOD}

The Ethics Committee of the University of Ibadan, Ibadan, approved this study. Twenty-one sexually matured female African giant rats (Cricetomys gambianus), aged between 26 and 28 weeks and weighing 800-950 g, were used in the present study. The animals were housed in temperature-controlled rooms, with a light regime of 12 hour light and 12 hour dark. Food and water were provided ad libitum.

Vaginal smears were taken daily at between 08:00 am and 09:00 am to determine the stages of the oestrous cycle as described by Oke \& Oke (1999). Only giant rats that exhibited at least two consecutive 5-day oestrous cycles were used in the study. Vaginal smears were taken prior to euthanasia to determine the stage of the oestrous cycle. Seven groups, each containing 3 animals, at different stages of oestrous cycle were identified as; Mid Proestrus (MP), Late Proestrus/Early Estrus (LP/EE), Mid Estrus (ME) groups as well as Mid Metestrus (MM), Late Metestrus/Early Diestrus (LM/ED), Mid Diestrus (MD) and Late Diestrus/Early Proestrus (LD/EP) groups.

The animals were euthanized with an overdose of sodium pentobarbitone and ovarian tissue obtained from all the rats were immersion-fixed in $2.5 \%$ glutaraldehyde in 0.1 $\mathrm{M}$ cacodylate buffer. Thereafter, the tissue samples were post-fixed in osmium tetroxide, dehydrated and embedded in epoxy resin. Ultrathin sections were stained with lead citrate and uranyl acetate. The samples were viewed with a Philips CMIO transmission electron microscope.

\section{RESULTS}

General Observations. Basic outer cortical and inner medullary zones were recognized in the ovary of the African giant rats at all stages of the oestrous cycle. The cortex contained oocytes enveloped by one or more layers of smaller cells to form ovarian follicles. The follicles were at different stages of development and vary greatly in size. Ultrastructural features of the germinal epithelium and the medullar of the ovary were similar at different stages of the oestrous cycle. The germinal epithelium was simple squamous with distinct slightly undulating basement membrane. Elongated indented nuclei displayed finely dispersed chromatin and prominent nucleoli. The nucleoli showed typical pars fibrosa, pars granulosa and pars amorpha. Junctional complexes occurred between adjacent germinal epithelial cells (Fig. 1). Cytoarchitecture of the

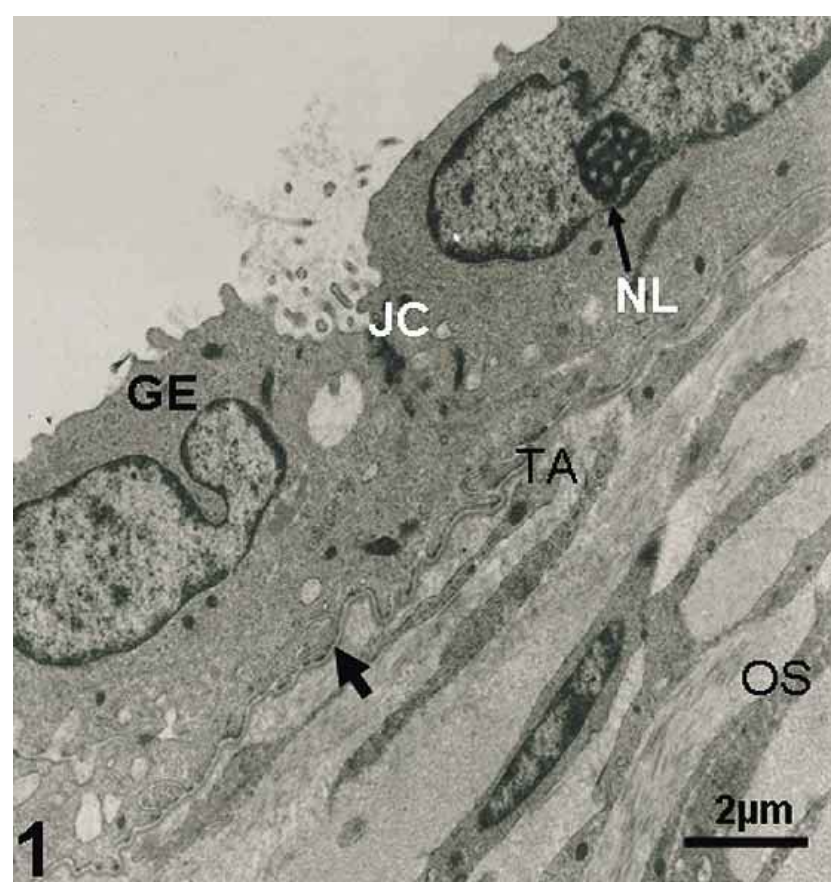

Fig. 1. Surface epithelium of the ovarian cortex at Mid Proestrus. Notice the junctional complex (JC) that linked the germinal epithelium (GE) which laid on the basement membrane (arrow) and tunica albuginae (TA) that laid on ovarian stroma (OS).

medulla showed numerous arterioles and venules, loose connective tissue and fibrocytes. Interstitial cells with numerous mitochondria and relatively large nuclei were observed (Fig. 2).

Mid Proestrus. At mid proestrus, there was disorganization of the inner part of the granulosa cells of secondary follicles to form the antrum. Cytoplasmic contents were discharged into the small lakes of colloid material that appeared among the stratified layers of granulosa cells. Ultrastructure of the disintegrating granulosa cell showed a paucity of organelles. Mitochondrial contents were discharged due to disintegration of its bilaminar membrane and profiles of endoplasmic reticulum were disorganized. Stacks of Golgi apparatus were dispersed and cytoplasmic matrix was cloudy (Figs. 3 and 4). At late proestrus/early estrus, antrum formation had advanced and there was evidence of reorganization of granulosa cells.

Mid Estrus. During mid estrus, Graafian follicles with organized theca interna and theca externa as well as few primary and secondary follicles were observed. Figures 5 and 6 show electron micrographs of Graafian follicle and its granulosa cells at different levels of magnification. Figure 7 shows an electron micrograph of the interface between the granulose cells and the theca interna while Figure 8 shows electron micrograph of the interface between theca interna and theca externa. 


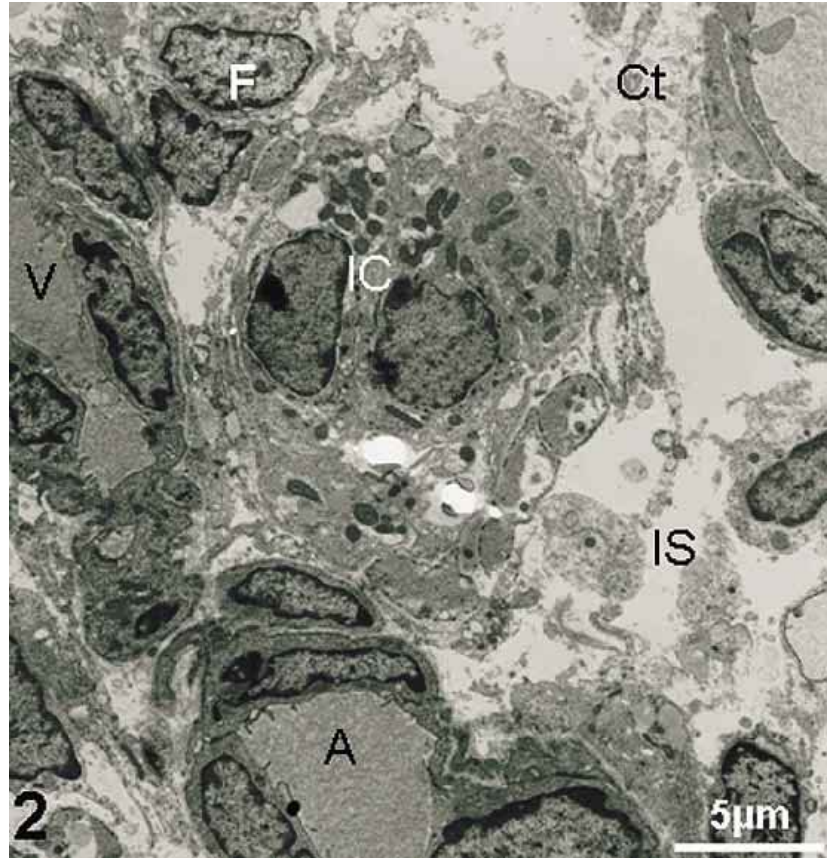

Fig. 2. Medulla of ovary at Mid Proestrus. Notice the numerous blood vessels: arterioles (A) and venules (V), spindle-shaped fibrocytes $(\mathrm{F})$ and interstitial cells (IC) as well as large deposits of connective tissues (Ct) and coalesced interstitial spaces (IS).

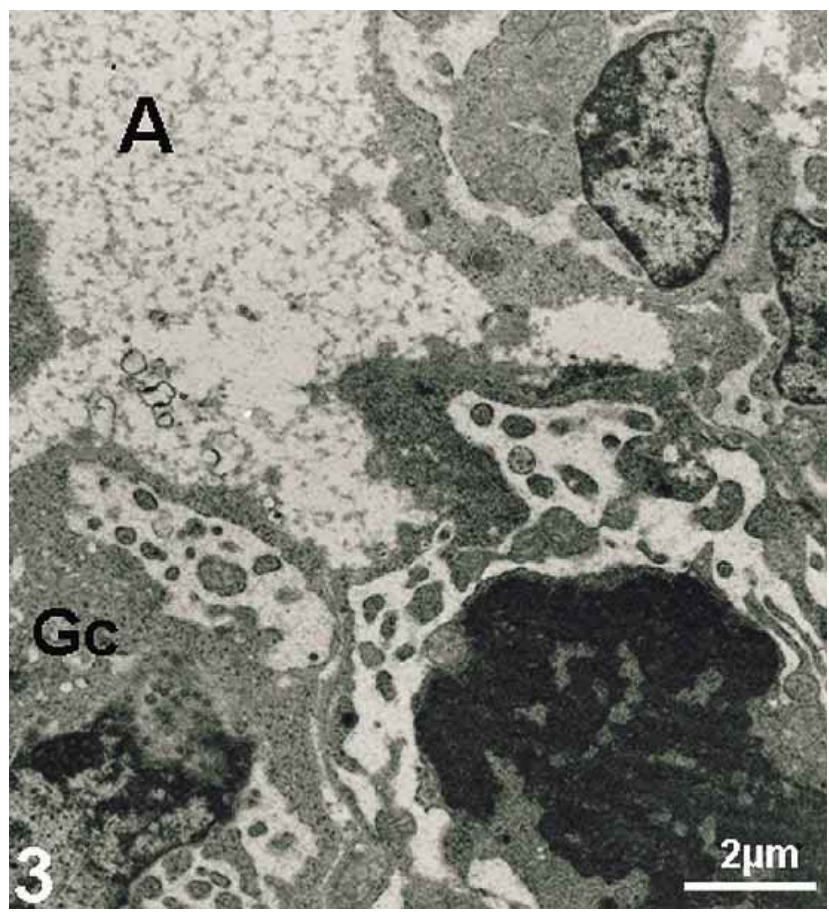

Fig. 3. Early formation of antrum at Mid Proestrus. Notice the island of antrum (A) being formed out of dissolution of granulosa cells $(\mathrm{Gc})$.

Graafian follicles contained cuboidal granulosa cells with relatively thin cytoplasm, abundant mitochondria, Golgi

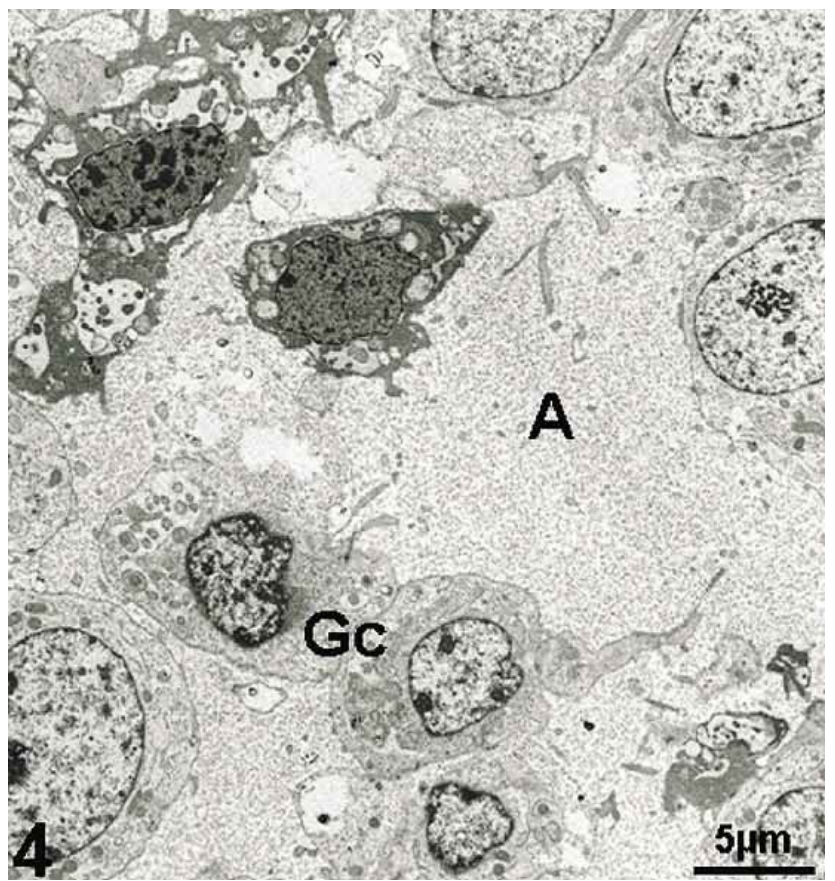

Fig. 4. Electron micrograph showing disintegration of granulosa cells to form antrum in Mid Proestrus. The accumulation of follicular fluid from granulosa cells ( $\mathrm{Gc}$ ) enlarge and coalesce to form a fluid-filled cavity, the follicular antrum (A).

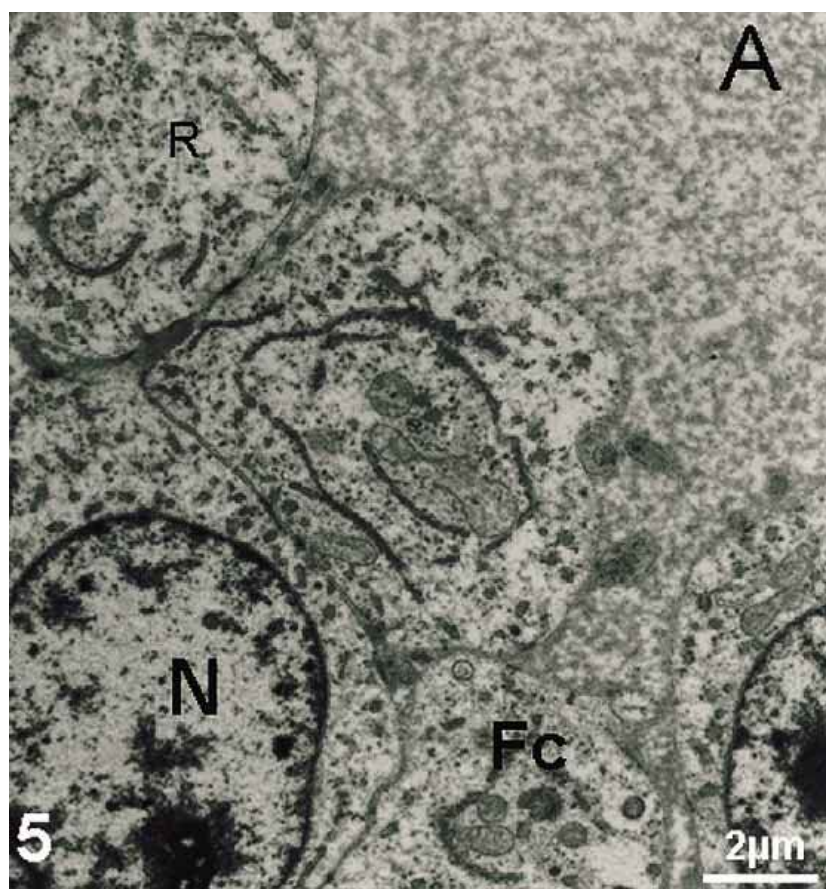

Fig. 5. Antral follicle in ovary at mid estrus showing apical layer of granulosa cells and the antrum. Notice the cuboidal granulosa cells $(\mathrm{G})$ containing numerous ribosomes $(\mathrm{R})$, large nucleus $(\mathrm{N})$ and overlaid by antrum (A).

regions and dense concentrations of ribosomes, both attached and unattached to endoplasmic reticulum (ER) cisternae (Fig 
5). Cell membranes were relatively straight and cytoplasm was thin-rimed due to high nuclear-cytoplasmic ratio. Cytoplasmic organelles occurred in moderate numbers.

Variably shaped mitochondria were evenly distributed in the cytoplasm while occasional giant mitochondria were also encountered. Profiles of rough and smooth endoplasmic reticulum (rER, sER) as well as moderate numbers of free ribosomes and polysomes were found throughout the cytoplasm. Profiles of Golgi apparatus were sparse (Fig. 6). The centrally located nuclei were ovoid in shape but often indented. Their nucleoplasm showed few clumps of heterochromatin but large areas of euchromatic materials and were encompassed by relatively straight nuclear envelope. Nucleoli of variable sizes and shapes containing pars fibrosa, pars granulosa and pars amorpha were regularly encountered (Fig. 5).

Several layers of granulosa cells were observed. The basal layer of granulosa cells rested on a well defined relatively straight basement membrane that overlaid the theca interna (Fig. 7). The boundary between the two theca layers was indistinct, as was that between the theca externa and the surrounding stroma (Fig. 8). The theca interna consisted of two to three concentric layers of cells. The cells appeared

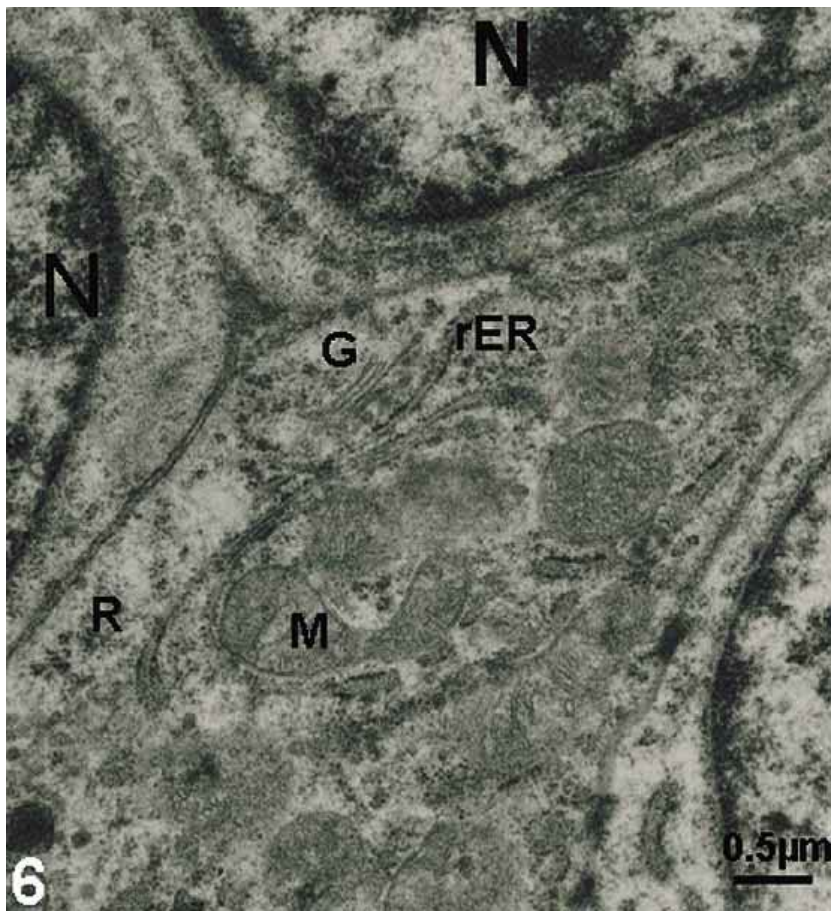

Fig. 6. Granulosa cell in antral follicle at mid estrus showing some cytoplasmic organelles. Notice mitochondria (M) of variable sizes and shapes, profiles of rough endoplasmic reticulum (rER), numerous free ribosomes $(\mathrm{R})$, large nuclei $(\mathrm{N})$ and Golgi apparatus $(\mathrm{G})$ are sparse in number.

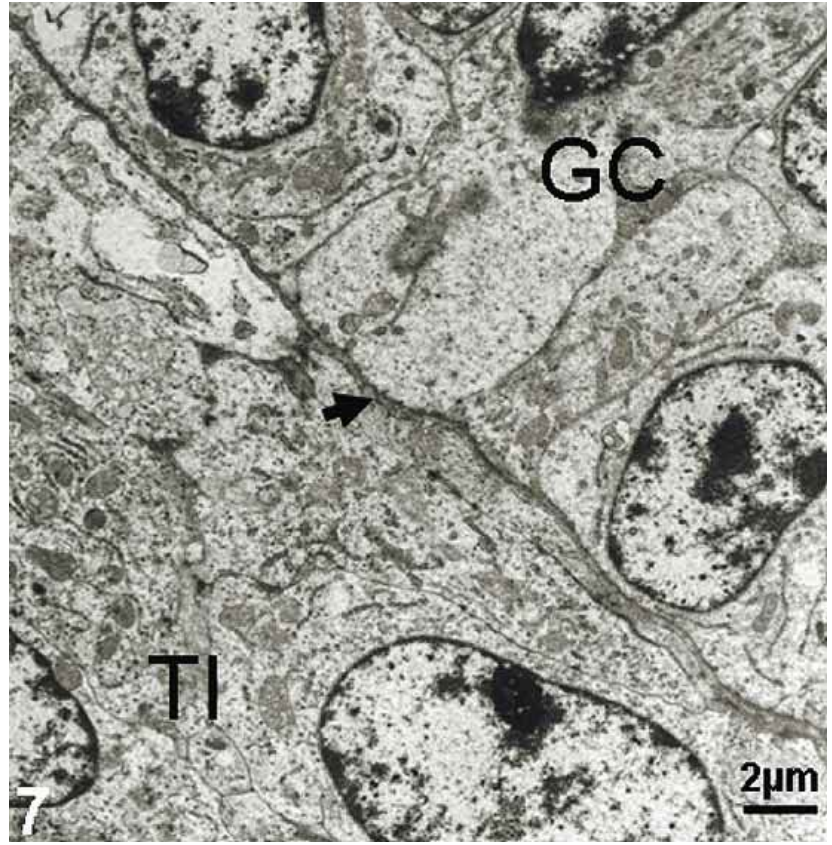

Fig. 7. Electron micrograph of the interface between the basal layer of Granulosa cells and peripheral layer of theca interna in antral follicle at mid estrus. Notice the basal granulosa cell layer (GC) separated from the theca interna (TI) by a distinct basement membrane (arrowed).

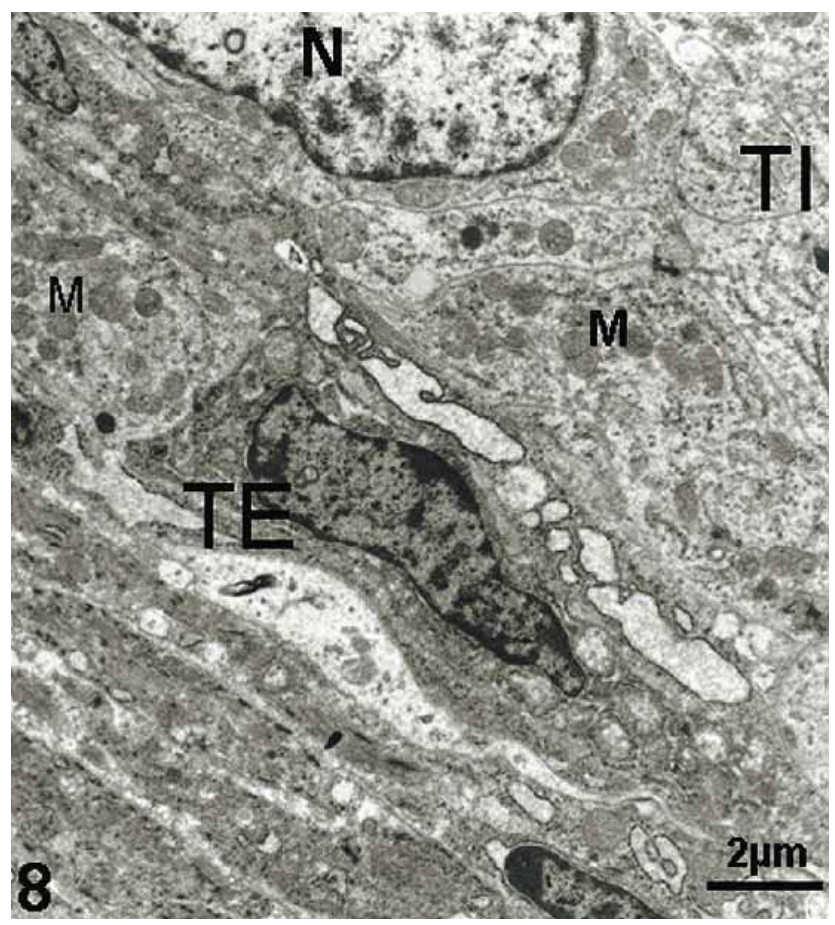

Fig. 8. The interface between theca interna and theca externa in antral follicle at mid estrus. Observe the theca interna (TI) having similar mitochondrial shape (M) with those in the theca externa (TE). Notice the elongated nucleus $(\mathrm{N})$ in theca interna as compared to the spindleshaped nucleus in the theca externa. 
ovoid and had centrally located round nucleus. Cellular ultrastructure did not differ significantly from that of granulosa cells but the nuclear-cytoplasmic ratio was lower. The number, size and distribution of mitochondria were much greater and wide spread in granulosa cells than in theca interna cells. Giant mitochondria were never observed (Figs. 7 and 8).

The theca externa displayed flattened cells that had moderate cytoplasmic organelles and elongated spindleshaped nuclei. Profiles of rough endoplasmic reticulum were sparse while aggregations of circular mitochondria were observed around the nucleus. Electron lucid vesicles of variable sizes and shapes were frequently encountered. The elongated spindle-shaped nuclei presented more areas of heterochromatin than euchromatin (Figs. 8 and 9).

Many individual primordial follicles, each consisting of a large oocyte, were observed at the periphery of the cortex having simple squamous follicular cells. Cellular ultrastructure revealed close apposition of plasma membrane of the oocytes and follicular cells at mid-estrus. The cytoplasm exhibited even distribution of polysomes and ribosomes as well as scanty network of intermediate filaments. The nuclei of the follicular cells were highly indented and displayed regions of heterochromatin and euchromatin (Fig. 10).

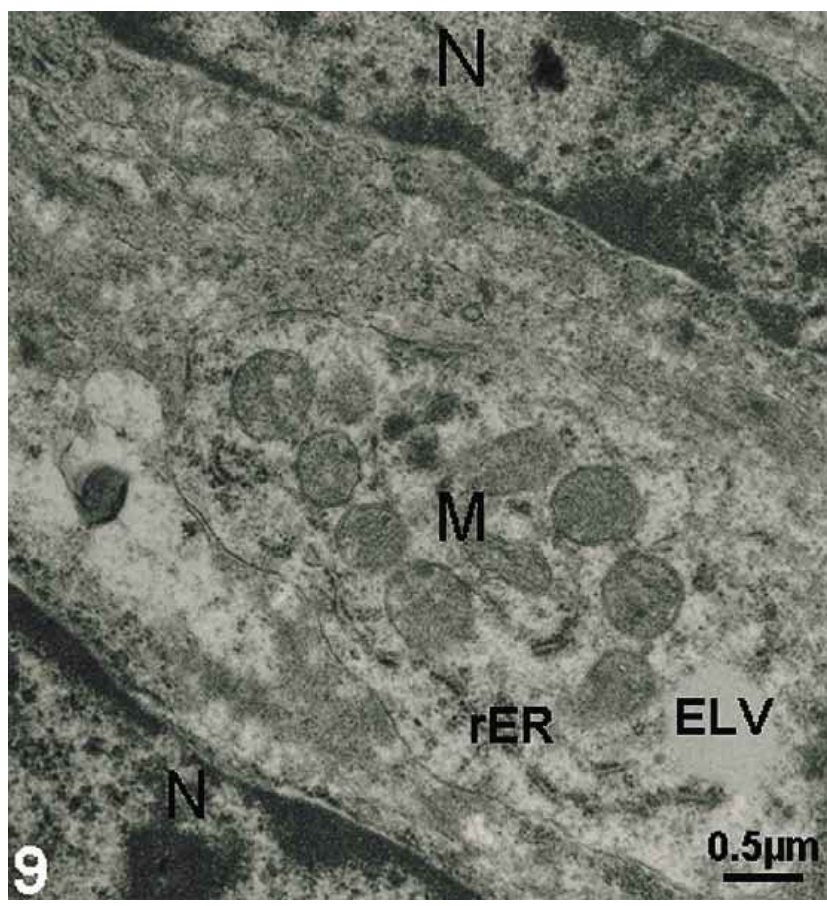

Fig. 9. Theca externa cells of an antral follicle at mid estrus. Notice the spindled-shaped elongated nuclei $(\mathrm{N})$, clustered mitochondria $(\mathrm{M})$ and sparse rough endoplasmic reticulum (rER). Electron lucid vesicles (ELV) were evenly distributed in the cytoplasm.

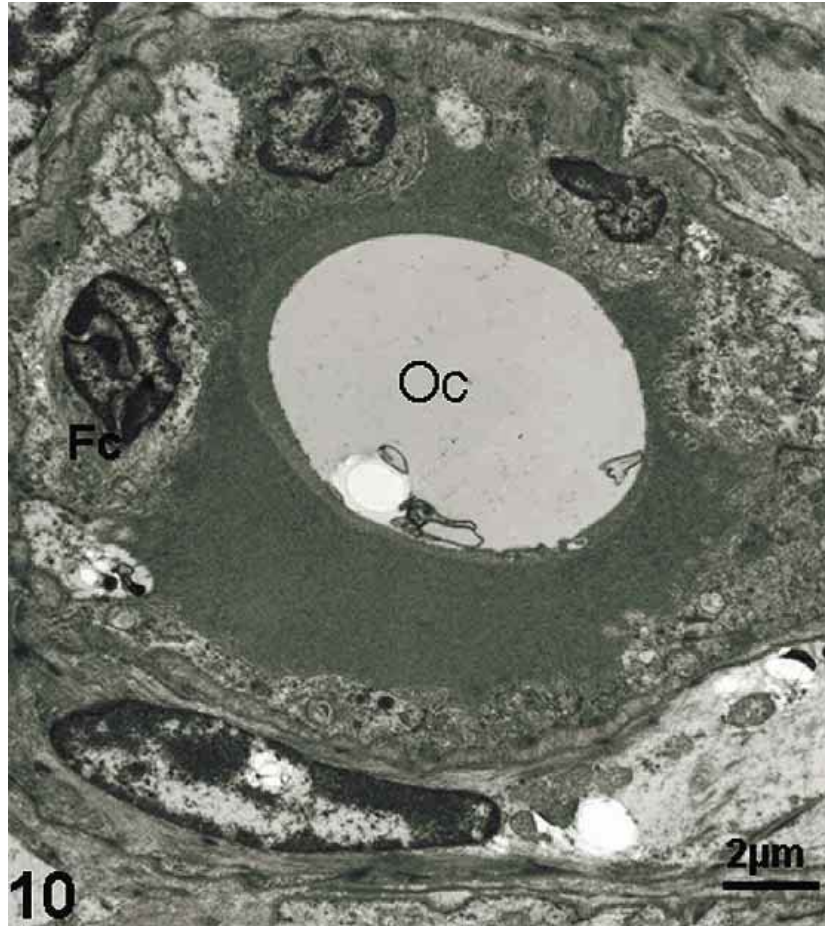

Fig. 10. A primordial follicle at mid estrus. Note the large oocyte (Oc) surrounded by follicular cells $(\mathrm{Fc})$.

Mid Metestrus. Cellular ultrastructure observed during mid metestrus showed commencement of differentiation of corpus luteum. There was progression of transformation of the granulosa cells to the luteal cells. The cellular contents were characterized by presence of fewer mitochondria, condensation of intermediate filaments and less cohesive cell-to-cell contacts (Fig. 11). The ultrastructural features during late metestrus/ early diestrus was similar to mid metestrus except that cellular differentiation had reached an advanced level.

Mid Diestrus. At mid diestrus, the general ultrastructural architecture of the ovarian follicles showed disorganized and disoriented cellular contents. The antrum-filled cavities of some of the antral follicles were lined by flattened cells with oblong nuclei and had layers of granulosa cells with indented nuclei. The oocyte suspended in the antrum contained large nucleus surrounded by electron lucid and electron dense materials, the cumulus oophorus (Fig. 12). The cytoplasm had free ribosomes, aggregates of round mitochondria and intermediate filaments. Ultrastructure of cells in the upper layer of granulosa cells displayed disorganized cellular organelles. Profiles of rough endoplasmic reticulum were less organized and disoriented while the elongated spindleshaped nuclei had clumps of heterochromatic materials and large areas of euchromatic materials (Fig. 13). High cellular activities similar to what obtained in the granulosa cells were 


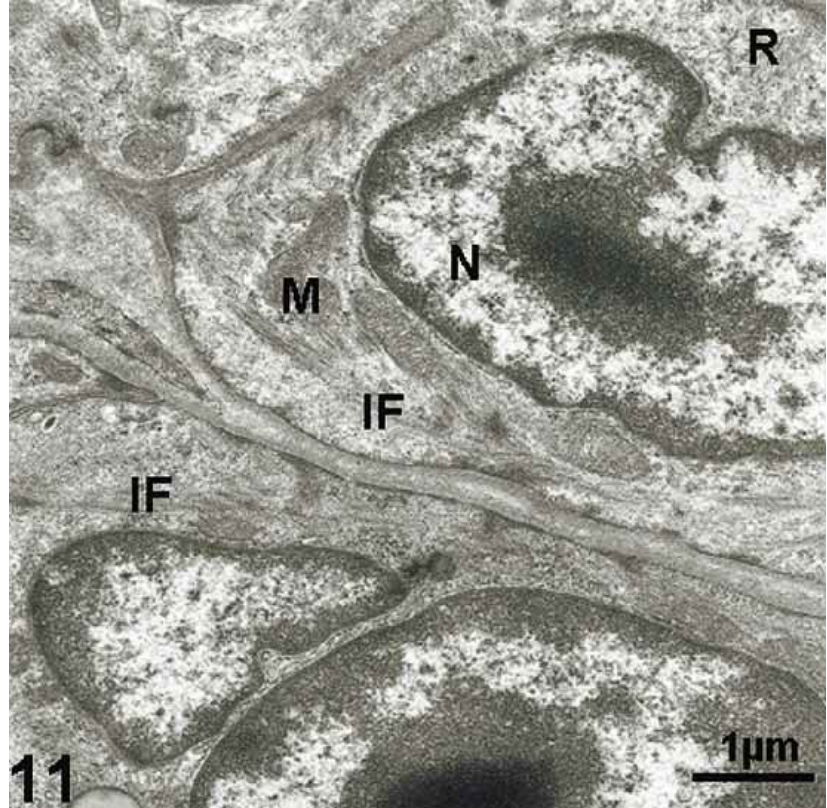

Fig. 11. Granulosa cells at Mid Metestrus. Notice the presence of ribosomes $(\mathrm{R})$, nuclei $(\mathrm{N})$ with large areas of heterochromatin, sparsely distributed mitochondria (M) and condensation of intermediate filaments (IF).

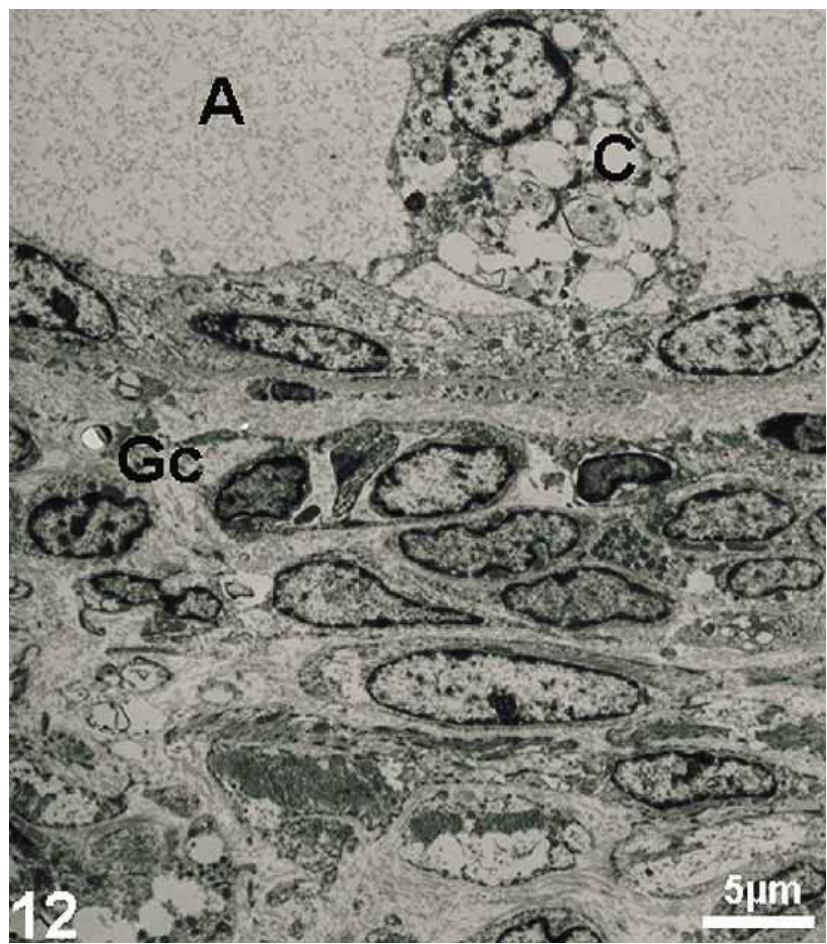

Fig. 12. An antral follicle at Mid Diestrus. Notice the cumulus oophorus (C) in the antrum (A) and granulosa cells (Gc) with flattened innermost layer that surrounds the antral cavity.

also observed in both the theca interna and theca externa. In addition, more condensed intermediate filaments, elongated mitochondria and large areas of electron-lucid regions as

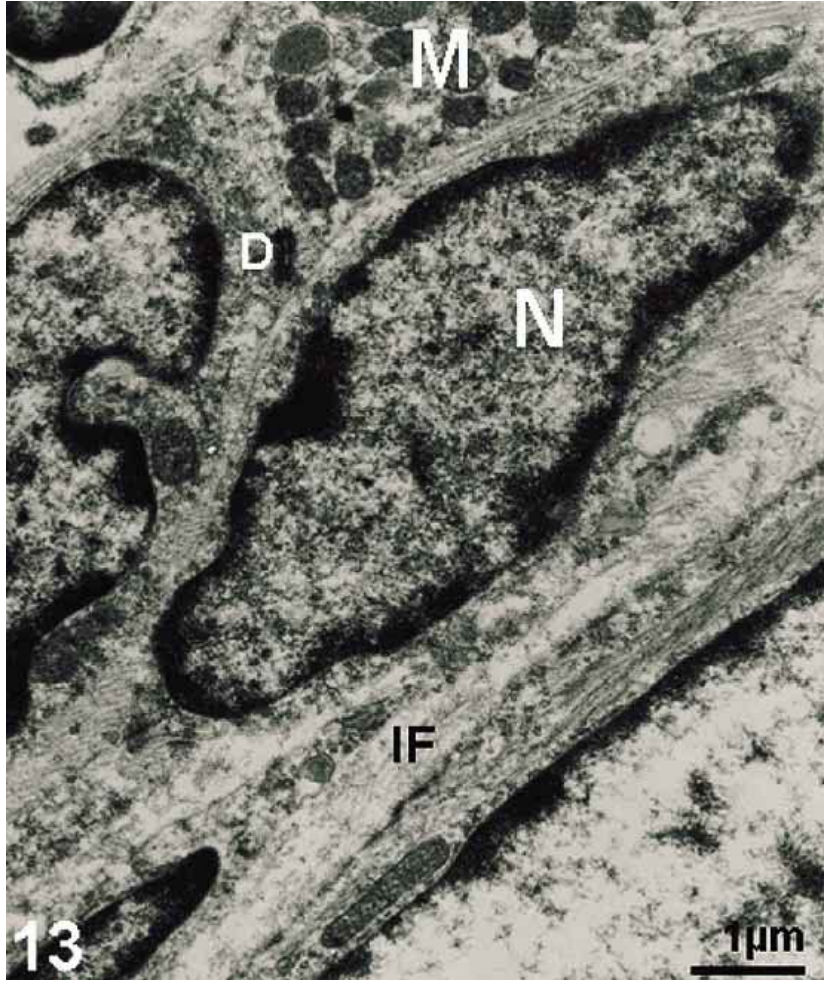

Fig. 13. Middle layer of granulosa cells at Mid Diestrus. Observe aggregation of round mitochondria (M), Desmosomes (D), elongated nucleus $(\mathrm{N})$ and condensed intermediate filaments (IF).

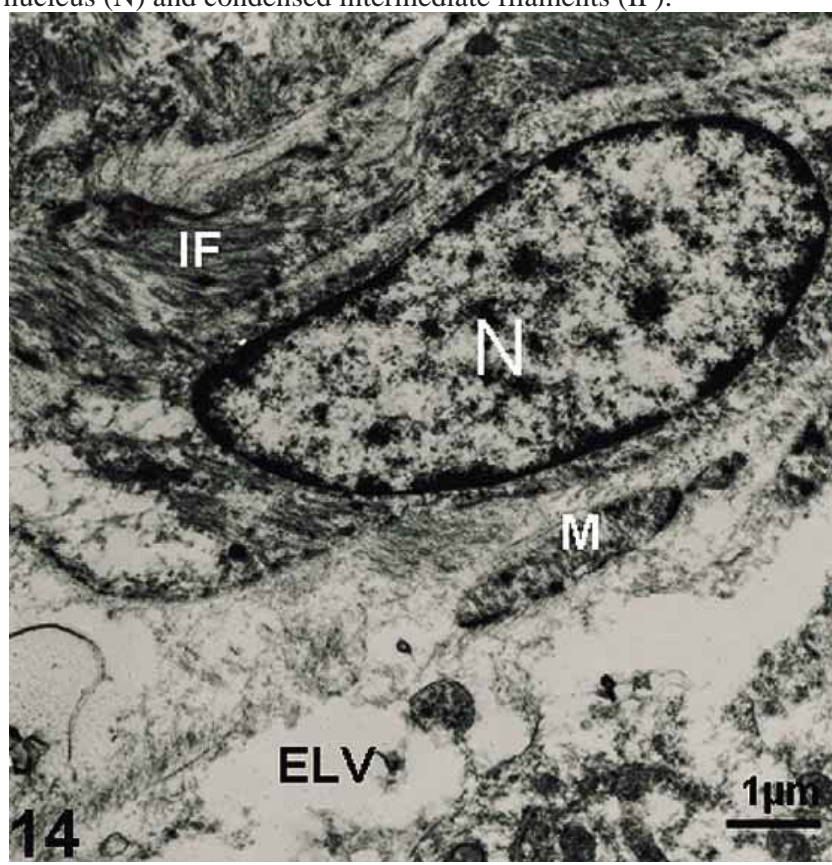

Fig. 14. Theca interna at Mid Diestrus. Notice the oval nucleus $(\mathrm{N})$ with clumps of heterochromatin, elongated mitochondria (M), condensed intermediate filament (IF) and coalesced electron-lucid vacuoles (V).

well as elongated, oval nuclei with focal areas of heterochromatic materials were observed (Fig. 14). 
During mid-diestrus, corpus luteum was recognized. Depolarization of the basement membrane that originally separated granulosa cells from the theca occurred. This depolarization allowed intercellular spaces to form between the granulosa cells and the theca interna. Cell ultrastructure revealed that granulosa cells and the theca interna were undergoing cytomorphosis. The granulosa cells enlarged, became polyhedral and were filled with lipid droplets. Mitochondria with tubular cristae and an abundant smooth endoplasmic reticulum were observed (Fig. 15).

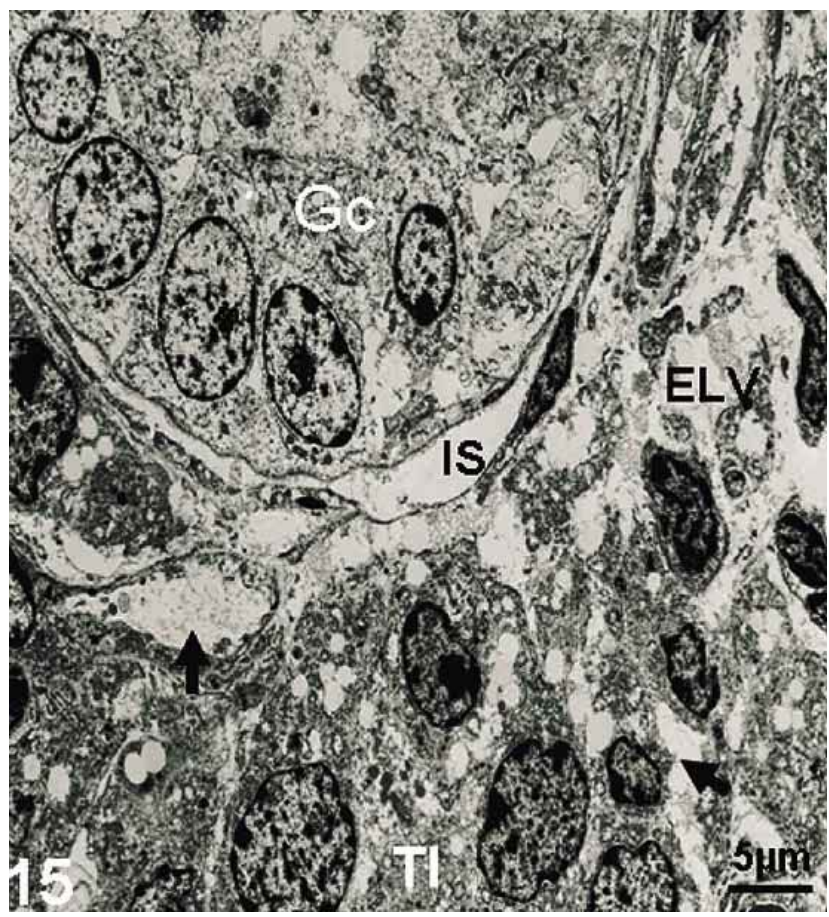

Fig. 15. Corpus luteum at Mid-Diestrus. Notice the intercellular space (IS) created when granulosa cells (Gc) detached from the basement membrane that separated them from the theca interna (TI). Observe the electron-lucid vesicles (ELV) and abundant lipid droplets (arrowed) distributed throughout the forming corpus luteum.

Late Diestrus/Early Proestrus. At late diestrus/early proestrus, granulosa cells displayed numerous mitochondria of varying sizes and shapes. Ribosomes were evenly distributed throughout the cytoplasm while electron lucid vesicles were sparsely distributed. Nuclear-cytoplasmic ratio was high and cell-to-cell contacts were cohesive while granulosa-theca contacts were smooth. Nuclei were centrally located and displayed finely dispersed chromatin. Nucleoli were prominent and nuclear indentations were of varying degrees (Fig. 16).

Figure 17 showed primordial follicle in late diestrus/ early proestrus. The oocyte had a large vesicular nucleus with finely dispersed chromatin and large nucleolus. Its nuclear envelope had well-developed pores. Short tubular

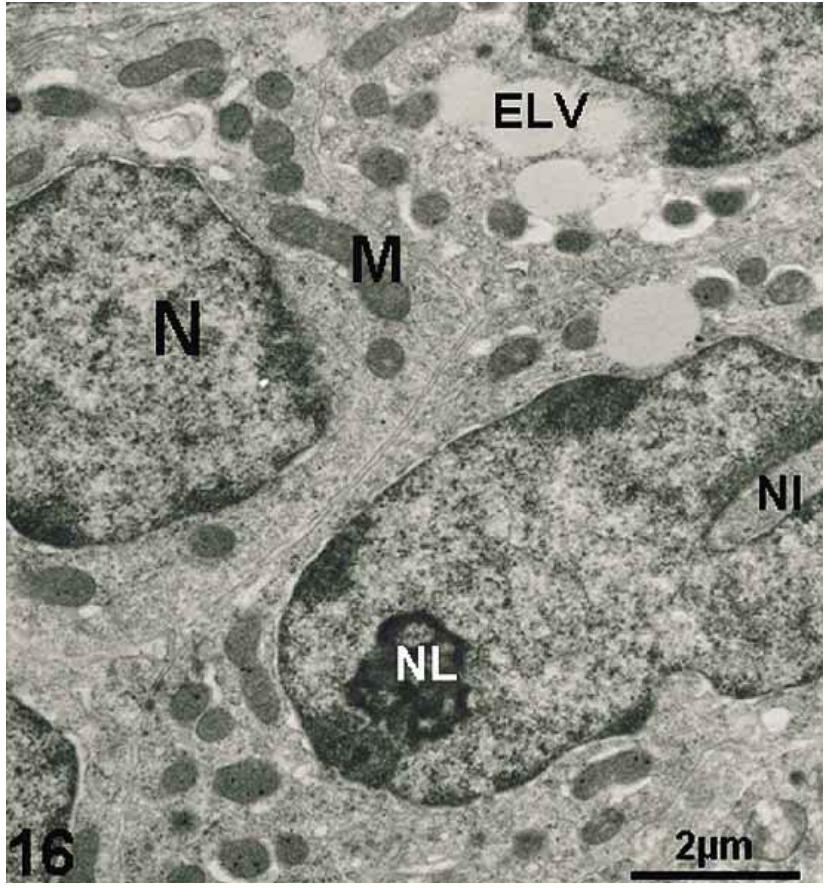

Fig. 16. Granulosa cells in Late Diestrus/Early Proestrus. Notice the Nucleus (N) with nuclear indentation (NI) and prominent nucleolus (NL). Observe proliferation of mitochondria (M) and presence of electron lucid vesicles (ELV).

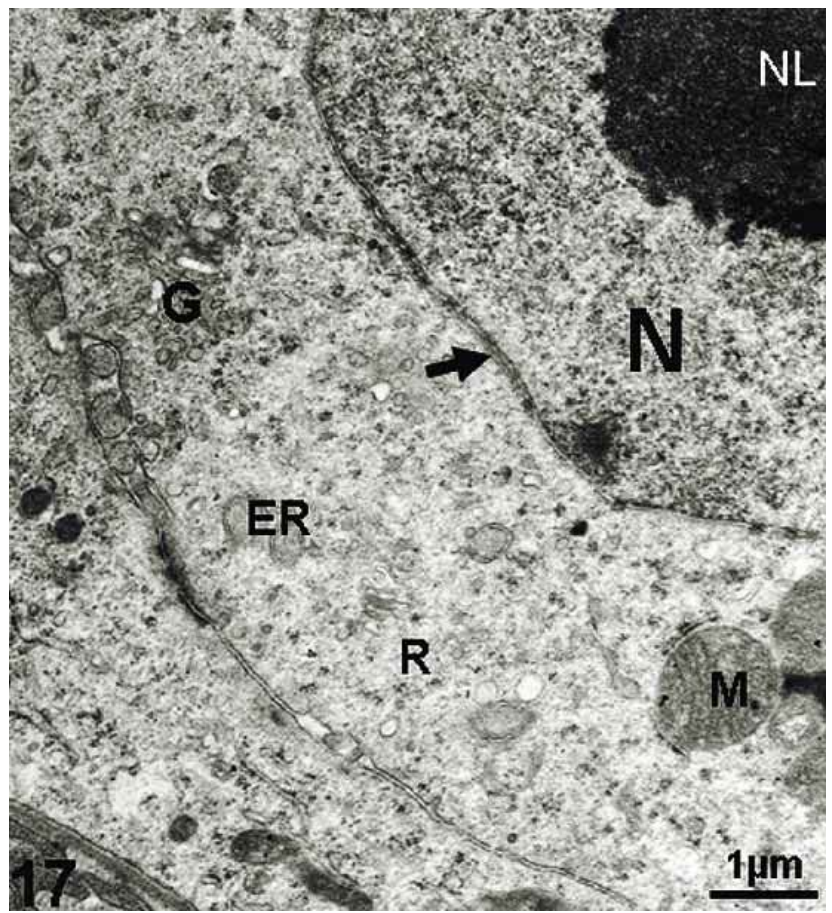

Fig. 17. An oocyte in primordial follicle at late diestrus/early proestrus. Notice the euchromatic nucleus (N) with large nucleolus (NL) and observe the nuclear envelope (arrow) that encompassed the nucleus. Also note the round mitochondria (M) with lamellar cristae and several vesicles of endoplasmic reticulum (ER), short Golgi apparatus $(\mathrm{G})$ as well as numerous free ribosomes (R). 
profiles of Golgi apparatus were located near the nucleus while numerous small vesicles represented endoplasmic reticulum. Round mitochondria with lamellar cristae were observed.

Secondary follicles identified at late diestrus/early proestrus, mid proestrus and late proestrus/early estrus had a fully grown oocyte surrounded by a well-developed zona pellucida, stratified granulosa cells as well as distinct theca interna and theca externa. They shared the same fine structures (Fig. 18). Cell ultrastructure of the oocyte displayed full compliment of cytoplasmic organelles. Mitochondria of varying sizes and shapes with lamellar cristae widely dispersed free ribosomes and rough endoplasmic reticulum as well as short profiles of Golgi apparatus and spherical electron dense vesicles were identified.

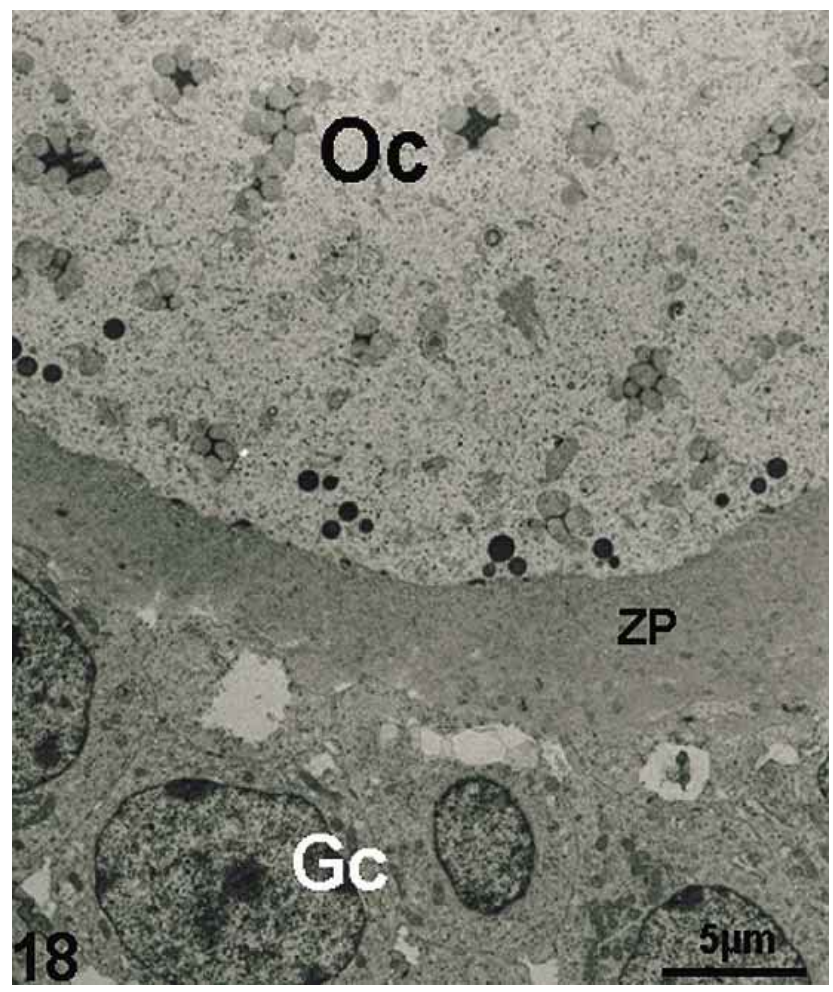

Fig. 18. Secondary follicle at Late Diestrus/Early Proestrus. Notice the oocyte $(\mathrm{Oc})$ with abundant cytoplasmic organelles surrounded by a well-developed zona pellucida and granulosa cells $(\mathrm{Gc})$ with large nuclei.

\section{DISCUSSION}

The current study has revealed that the ovarian cortex of the sexually matured female African giant rat contained many individual primordial unilaminar follicles, preantral and antral follicles as well as Graafian follicles and corpus luteum at different phases of maturation during oestrous cycle. Their ultrastructure were similar to those previously reported for several mammals (Porter \& Bonneville, 1973; Webley et al., 1990). Numerous variably shaped mitochondria with lamellar cristae, profiles of Golgi complexes and dense concentrations of ribosomes, both unattached and attached to endoplasmic reticulum cisternae, were present. The cells of the theca interna shared fine structure with the granulosa cells. They contain, in addition, lipid droplets and smooth endoplasmic reticulum, thereby suggesting steroid-secreting cells. These steroid-secreting features observed lent credence to various titers of estrogenic hormones reported at different stages of oestrus cycle.

The fully-grown oocyte observed in secondary follicles at late diestrus/early proestrus was surrounded by a well-developed zona pellucida, stratified granulosa cells as well as distinct theca interna and theca externa. The fine structure of the oocyte in giant rat was similar to the previous report on the ultrastructure of oocyte in other species of laboratory animals (Weiss, 1983). Zona pellucida has been described as a highly retractile layer of condensed glycoprotein secreted into spaces between the oocyte and the innermost granulosa cells. The granulosa cells and the oocyte are in communication via gap junctions between filiform processes that extend from each into the zona pellucida (Fawcett \& Jensh). The ultrastructure of the zona pellucida observed in this study shared similar features with what has been described by the previous authors as it was shown to exhibit series of network that connected the oocyte and the granulosa cells.

Results from the present study showed that at mid proestrus, there was disorganization of the inner part of the granulosa cells of secondary follicles to form the antrum. Cytoplasmic contents were observed to be discharged into the small lakes of colloid material that appeared among the stratified layers of granulosa cells. Ultrastructure of the disintegrating granulosa cells showed a paucity of organelles. Mitochondrial contents were discharged due to disintegration of its bilamina membrane and profiles of endoplasmic reticulum were disorganized. Stacks of Golgi apparatus were dispersed and cytoplasmic matrix was observed to be cloudy. This is the first time antral formation is being described in African giant rat and is in accordance with reports by other workers (Weiss; Fawcett \& Jensh; Eurell \& Frappier).

The transformation of the ovulatory follicles into corpus luteum has been shown to involve first the depolarization of the basement membrane that originally separated the granulosa cells layer from the theca. This depolarization allows the connective tissue cells and blood vessels to invade the stratum granulosum (Weiss). The 
present study revealed similar features in the ovary of African giant rat at mid diestrus. Corpus luteum development depends on dramatic tissue remodeling as well as sequential regulation of vascular outgrowth and regression. This process includes rapid proliferation of luteinized theca and granulosa cells along with a wave of vascular sprouting that eventually regress as the corpus luteum ages during luteolysis (Redmer et al., 2001; Fraser \& Wulff, 2001; Geva \& Jaffe, 2000). The extensive follicular tissue growth and vascularization is regulated in part by various HS-bound proliferation and angiogenesis promoting factors, such as $\mathrm{FGF}_{2}$ (Fraser \& Wulff; Peluso et al., 2001). Results from this study revealed that the general ultrastructural architecture of the ovarian follicles displayed disorganized and disoriented cytoplasmic organelles at mid diestrus. The spatial distribution of the intermediate filament within the cell depicts that it is subjected to considerable stress, suggesting that they resist tension within cells and serve a structural role. They may stabilize the nucleus in position (Bozzola \& Russell, 1999). The numerous mitochondria and lipid granules observed in the cytoplasm of corpus luteum of giant rat at mid diestrus in this study as well as an abundant smooth endoplasmic reticulum and a well-developed Golgi apparatus are consistent with characteristics of steroid-secreting cells previously described in other species of animals (Weiss; Webley et al.; Eurell \& Frappier).

AKINLOYE,A. K. \& OKE, B. O. Características ultraestructurales durante el ciclo estral en ovario de la rata gigante africana (Cricetomys gambianus, Waterhouse). Int. J. Morphol., 32(2):558-567, 2014.

RESUMEN: El presente estudio describe las estructuras específicas del ovario durante el ciclo estral en ratas gigantes africanas (Cricetomys gambianus Waterhouse). Las características ultraestructurales del epitelio germinal y medular del ovario fueron similares durante las diferentes etapas del ciclo estral. A mediados del período proestro, se observó una desorganización de la capa interna de las células de la granulosa, de folículos secundarios para formar el antro folicular. A fines del proestro/ciclo estral temprano, se observó un avance de la formación del antro y fue posible evidenciar la reorganización de las células de la granulosa. Las estructuras finas del ovario durante mediados del ciclo estral incluyen folículos con mitocondrias en forma variable, perfiles de complejos de Golgi y densa concentración de ribosomas. La teca interna compartida, evidenció ultraestructura similar a las células de la granulosa, que además contienen las gotas de lípidos y retículo endoplásmico liso. La ultraestructura celular que observamos durante mediados del ciclo estral mostró el comienzo de la diferenciación del cuerpo lúteo. A mediados del ciclo diestro, la formación ultraestructural de los folículos mostró un contenido celular desorganizado y se observó el cuerpo lúteo con despolarización de la membrana basal que separa las células de la granulosa de teca. Al término del período diestro al comienzo del proestro, se observaron numerosas mitocondrias de diversos tamaños y formas en las células de la granulosa. En el citoplasma, los ribosomas se distribuyeron de manera uniforme, mientras que los electrones lúcidos de vesículas estaba escasamente distribuidas. Los resultados de este estudio indican que los cambios finos estructurales en el ovario de la rata gigante durante el ciclo estral son similares a los de los roedores de laboratorio.

PALABRAS CLAVE: Ultraestructura ; Ovario; Ciclo estral; Rata gigante africana.

\section{REFERENCES}

Ajayi, S. S. The Biology and Domestication of the African giant rat (Cricetomys gambianus Waterhouse). PhD Thesis. Ibadan, University of Ibadan, 1974.

Ajayi, S. S. Field observations on the African giant rat Cricetomys gambianus Waterhouse in southern Nigeria. Afr. J. Ecol., 15(3):191-8, 1977.

Akinloye, A. K. \& Oke, B. O. Gross morphometry of ovary of the female African giant rats (Cricetomys gambianus, Waterhouse) at different stages of the oestrous cycle. Trop. Vet., 27(1):10-6, 2009.

Bozzola, J. J. \& Russell, L. D. Electron Microscopy: Principles and Techniques for Biologists. 2nd ed. London, Jones \& Bartlett Publishers, 1999. pp.477-8.

Eurell, J. A. \& Frappier, B. L. Female Reproductive System. In: Dellmann's Textbook of Veterinary Histology. $6^{\text {th }}$ ed. Oxford, Blackwell Publishing, 2006. pp.256-78.
Fawcett, D. W. \& Jensh, R. P. Female Reproductive System. In: Bloom \& Fawcett's: Concise Histology. $2^{\text {nd }}$ ed. Malta, Arnold Publishers, 2002. pp.283-96.

Fraser, H. M. \& Wulff, C. Angiogenesis in the primate ovary. Reprod. Fertil. Dev., 13(7-8):557-66, 2001.

Geva, E. \& Jaffe, R. B. Role of vascular endothelial growth factor in ovarian physiology and pathology. Fertil. Steril., 74(3):42938,2000 .

Hafez, E. S. E. Reproduction and Breeding Techniques for laboratory Animals. Philadelphia, Lea \& Febiger, 1970.

Madekurozwa, M. C.; Oke, B. O. \& Akinloye, A. K. The immunohistochemical localization of desmin and smooth muscle actin in the ovary of the African giant rat (Cricetomys gambianus) during the oestrous cycle. Anat. Histol. Embryol., 39(1):81-6, 2010. 
Oke, O. A. \& Oke, B. O. Vaginal cytological changes during the oestrous cycle of the adult female African giant (C. gambianus, Waterhouse). Trop. Vet., 17:169-80, 1999.

Peluso, J. J.; Pappalardo, A. \& Fernandez, G. Basic fibroblast growth factor maintains calcium homeostasis and granulosa cell viability by stimulating calcium efflux via a PKC deltadependent pathway. Endocrinology, 142(10):4203-11, 2001.

Porter, K. R. \& Bonneville, M. A. The Ovarian Follicle. In: Fine Structure of Cells and Tissues. $4^{\text {th }}$ ed. Philadelphia, Lea \& Febiger, 1973. pp.93-4.

Redmer, D. A.; Doraiswamy, V.; Bortnem, B. J.; Fisher, K.; Jablonka-Shariff, A.; Grazul-Bilska, A. T. \& Reynolds, L. P. Evidence for a role of capillary pericytes in vascular growth of the developing ovine corpus luteum. Biol. Reprod., 65(3):879-89, 2001.

Webley, G. E.; Richardson, M. C.; Smith, C. A.; Masson, G. M. \& Hearn, J. P. Size distribution of luteal cells from pregnant and non-pregnant marmoset monkeys and a comparison of the morphology of marmoset luteal cells with those from the human corpus luteum. J. Reprod. Fertil., 90(2):427-37, 1990.

Weiss, L. The female reproductive system. In: Histology, Cell and Tissue Biology. $5^{\text {th }}$ ed. Elsevier Science Publishing, 1983. pp.914-43.

\author{
Correspondence to: \\ Dr. A. K. Akinloye \\ Department of Veterinary Anatomy \\ Federal University of Agriculture \\ P. M. B. 2240, Abeokuta \\ NIGERIA
}

Email: akinloyeak@unaab.edu.ng

Received: 17-02-2013

Accepted: 10-02-2014 